\title{
耐アルカリガラス繊維補強セメント打込み型枠を用いた $\mathrm{RC}$ 梁の耐火性能に関する考察
}

\author{
藤田 直明 ${ }^{* 1}$ ・平居 孝之 ${ }^{* 2} \cdot$ 村上 聖*3 ・佐藤 嘉昭*4
}

概 要 耐アルカリガラス繊維補強セメント打込み型枠（以下では GRC 打込み型枠と表す）を使用した RC 梁の火災時に おける GRC 打込み型枠とコンクリートの接合面に発生する応力を 3 次元有限要素法による数值計算にて調へた。その結果, $\mathrm{GRC}$ 打込み型染の底板と側板の境目近傍で，GRC 打込み型枠とコンクリートの接合面（以下では接合面と表す）に大きな引 張り応力およびせん断応力が発生することが判明した。先に行われた基礎実験 ${ }^{1) ~ 3) ~}{ }^{3}$ から, 円形凹み内面形状の GRC 打込み 型枠（以下では円形凹み GRC 打込み型枠と表す）之，金網埋設内面形状の GRC 打込み型枠（以下では金網埋設 GRC 打込 み型枠と表す）がコンクリートとの接合性に優れた結果を示したことから，これらの内面形状を有し，底板と側板が一体と なったGRC 打込み型枠を作成し，これらを使用した RC 梁について加熱試験を行い耐火時の挙動を調べた。その結果，金網 埋設 $\mathrm{GRC}$ 打込み型枠 $\mathrm{RC}$ 梁試験体は加熱試験後も耐火上有害な GRC 打込み型枠とコンクリートの分離は見られず，鉄筋の 昇温もコンクリートのみの RC 梁試験体と同様な傾向を示した。円形凹み $\mathrm{GRC}$ 打込み型枠 $\mathrm{RC}$ 梁試験体については, 他の試 験体に比べて鉄筋の昇温はいくぶん低く，これは GRC 打込み型染の部分的な剝離で形成された断熱層の影響と考えられる。

キーワード : 耐アルカリガラス繊維補強セメント, 打込み型枠, $\mathrm{RC}$ 梁, 耐火性能, 付着性能

\section{1.はじめに}

耐アルカリガラスの短繊維を分散させて混入して補強 したセメント製品（以下では GRC と表す）は, 1968 年 に英国の Building Research Establishment の Dr. Majumdar らにより基礎的な研究が行われ，その後工 業製品の開発へ発展した ${ }^{4)}$ 。GRC に関する基本技術は 日本にも導入され, 国内でも GRC の商品開発が盛んに 行われた5),6)。

GRC は, 不燃性, 造形性, 高強度などの特性を生か して, カーテン・ウオールや防音壁などに広く使われて いるが，その極めて高い中性化抑制効果を生かした製品 はまだない。筆者らは建築構造物の RC 部材の打込み 型枠に GRC を適用することに着目し，GRC 打込み型 枠を用いた梁の曲げによる部材構造試験 ${ }^{7)}$,8), 炭酸ガ スによる促進中性化試験 ${ }^{9)}$, 実構造物への施工試験 ${ }^{10)}$ を行って検討し, その可能性があることを示した。さら に建築物に広く用いられるようになるには建築基準法に 定められた耐火構造に指定されることが必要である。

そこで本研究では, GRC 打込み型枠を用いた RC 梁 の耐火性能について調べた。GRCのように高強度で不

$* 1$ 大分大学大学院工学研究科 (正会員)

*2 大分大学工学部 教授 (正会員)

* 3 熊本大学工学部 助教授 (正会員)

*4 大分大学工学部 教授 (正会員)
燃のセメント系材料を用いたパネルを打込み型枠に適用 する研究が多く行われているが, その厚さをかぶり厚さ に含めるのではなく捨て型枠として考えており, 打込み 型枠とコンクリートとの接合性について検討した研究は 少ない。耐火試験において GRC 打込み型枠とコンク リートが接合面で分離すると判定条件を満たさないの で，筆者らは GRC 打込み型枠とコンクリートとの接合 性を十分に得ることが, GRC 打込み型枠をかぶり厚さ に含めるために重要であると考えて研究を行った。

2. $\mathrm{GRC}$ 打込み型枠の接合面と構成に関 する検討

\section{1 火災時の接合面に生じる応力の数值解析}

GRC 打込み型枠を用いた RC 梁は, 火災時に内部の 位置によって温度が異なり材料定数が変わるため, 接合 面に両者を分離させるような応力が生じると考えられ る。ここでは, その応力の解析を 3 次元有限要素法によ る数值計算で行った。

\section{(1) 解析モデル}

図-1 に示す GRC 打込み型枠を用いた梁の耐火試験 体について, 太い点線で囲った ABCDEFGH の直方体 の部分を解析の対象にした。GRC 打込み型枠の厚さは $15 \mathrm{~mm}$ とし，配筋は図-2 と図-3のように設定した。 鉄筋はいずれも矩形断面とした。GRC 打込み型枠を含 んだかぶり厚さは, あばら筋が $30 \mathrm{~mm}$, 主筋が $40 \mathrm{~mm}$ 
である。

JIS A 1304 建築構造部分の耐火試験方法に示された 加熱温度曲線で加熱した時の 10 分, 20 分, 30 分, 40 分, 60 分, 80 分, 120 分経過時について, 加熱面すなわ ち解析モデルでは図-1 の ABCD の面, ABFE の面お よび BCGF の面からの距離が 0 ～15, 15〜30, 30〜40, 40〜60, 60〜90, 90〜125 mm の区域に分け, これらに 位置する有限要素の温度, 線膨張量および線形弾性を仮 定したときのヤング率を, 文献 11)〜14) を参考にして 表-1のように設定した。なおポアソン比はコンクリー トについて高温になると増加する場合と減少する場合が 示された文献 15) があるが, 他に適当な参考値がなく常 温の值と同じと仮定し，コンクリートと GRC は 0.2 , 鉄筋は 0.3 とした。

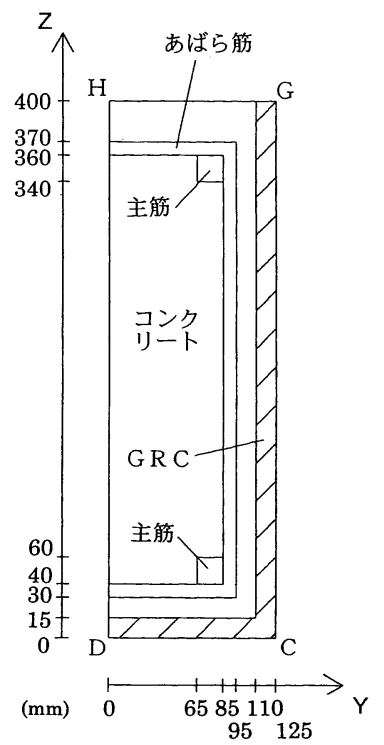

図-2 GRC 打込み型枠 RC 梁 $\mathrm{Y}-\mathrm{Z}$ 断面図

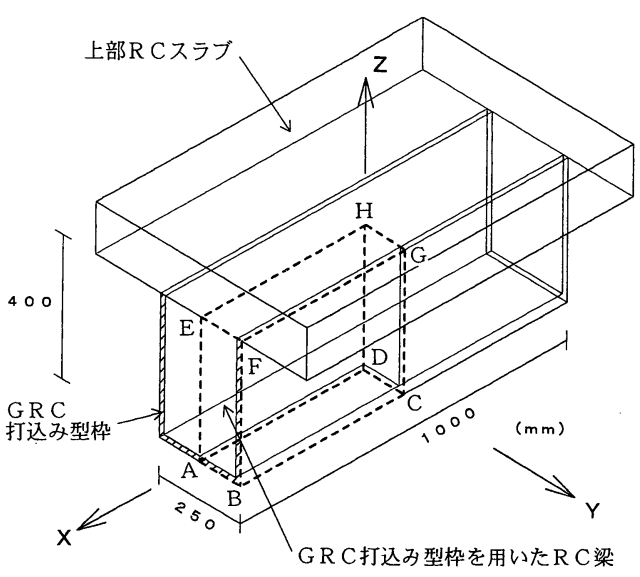

図-1 GRC 打込み型枠を用いた RC 梁

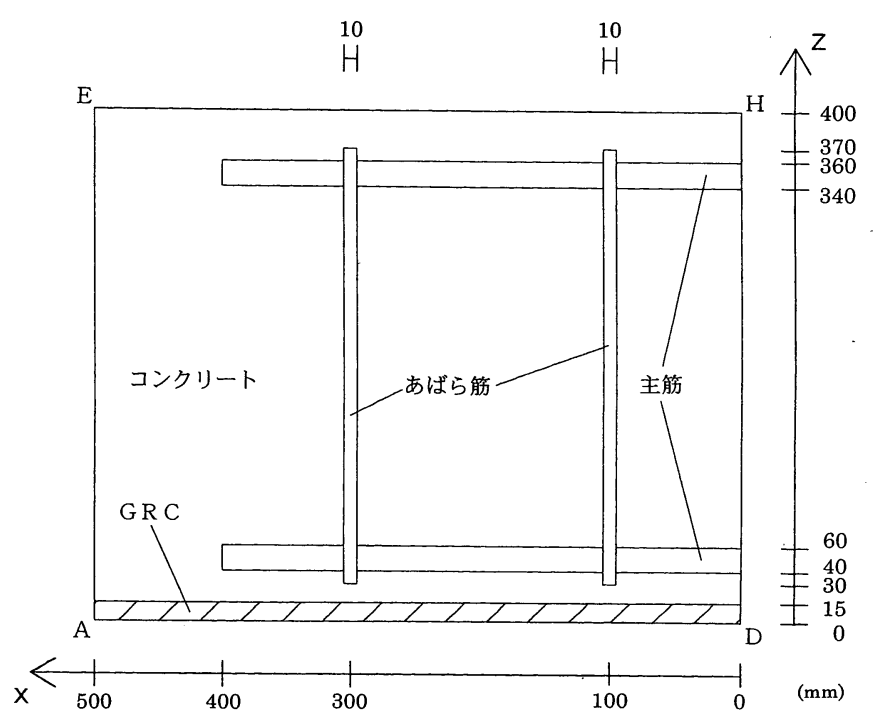

図-3 GRC 打込み型枠 $\mathrm{RC}$ 梁 $\mathrm{X}-\mathrm{Z}$ 断面図

表-1 梁の構成材料の物性値の加熱経時変化

\begin{tabular}{|c|c|c|c|c|c|c|c|c|c|c|c|c|c|c|c|c|c|c|c|c|c|c|c|c|c|}
\hline & \multirow{2}{*}{$\begin{array}{c}\text { 加熱面か } \\
\text { らの距離 } \\
\text { mm }\end{array}$} & \multicolumn{3}{|c|}{ 初期 } & \multicolumn{3}{|c|}{10 分加熱 } & \multicolumn{3}{|c|}{20 分加熱 } & \multicolumn{3}{|c|}{30 分加熱 } & \multicolumn{3}{|c|}{40 分加熱 } & \multicolumn{3}{|c|}{60 分加熱 } & \multicolumn{3}{|c|}{80 分加熱 } & \multicolumn{3}{|c|}{120 分加熱 } \\
\hline & & $t$ & $E$ & $\phi$ & $t$ & $E$ & $\phi$ & $t$ & $E$ & $\phi$ & $t$ & $E$ & $\phi$ & $t$ & $E$ & $\phi$ & $t$ & $E$ & $\phi$ & $t$ & $E$ & $\phi$ & $t$ & \begin{tabular}{|l|}
$E$ \\
\end{tabular} & $\phi$ \\
\hline \multirow{6}{*}{$\begin{array}{l}\text { コンク } \\
\text { リート }\end{array}$} & $0 \sim 15$ & \multirow{6}{*}{20} & \multirow{6}{*}{220} & & 280 & 157 & 22 & 430 & 130 & 47 & 520 & 115 & 65 & 610 & 103 & 83 & 710 & 87 & 108 & 790 & 73 & 131 & 800 & 72 & 134 \\
\hline & $15 \sim 30$ & & & & 180 & 177 & 12 & 280 & 157 & 22 & 360 & 141 & 35 & 430 & 130 & 47 & 550 & 111 & 71 & 650 & 97 & 95 & 680 & 92 & 103 \\
\hline & $30 \sim 40$ & & & & 140 & 136 & 9 & 210 & 170 & 15 & 270 & 159 & 21 & 320 & 147 & 29 & 440 & 129 & 49 & 540 & 112 & 69 & 590 & 106 & 80 \\
\hline & $40 \sim 60$ & & & & 110 & 194 & 6 & 160 & 182 & 10 & 200 & 172 & 14 & 230 & 165 & 17 & 340 & 144 & 32 & 430 & 130 & 47 & 490 & 121 & 58 \\
\hline & $60 \sim 90$ & & & & 60 & 206 & 3 & 90 & 201 & 4 & 110 & 194 & 6 & 120 & 191 & 7 & 210 & 170 & 15 & 290 & 154 & 24 & 370 & 139 & 36 \\
\hline & $90 \sim 125$ & & & & 30 & 217 & 0.5 & 40 & 214 & 1 & 45 & 212 & 2 & 50 & 211 & 2 & 120 & 191 & 7 & 190 & 174 & 13 & 260 & 161 & 20 \\
\hline GRC & $0 \sim 15$ & 20 & 250 & 0 & 280 & 192 & 37 & 430 & 159 & 58 & 520 & 139 & 71 & 610 & 118 & 84 & 710 & 104 & 110 & 790 & 93 & 135 & 800 & 90 & 137 \\
\hline あばら筋 & $30 \sim 40$ & 20 & 2100 & 0 & 140 & 2020 & 12 & 2101 & 1960 & 20 & 2701 & 1900 & 28 & 320 & 1840 & 35 & 440 & 1630 & 53 & 540 & 1280 & 74 & 590 & \begin{tabular}{|l|}
990 \\
\end{tabular} & 78 \\
\hline 筋 & $40 \sim 60$ & 20 & 2100 & 0 & 110 & 2050 & 9 & 1602 & 2000 & 14 & 200 & 970 & 19 & 230 & 1950 & 23 & 340 & 1810 & 38 & 430 & 1660 & 51 & 490 & 1490 & 61 \\
\hline \multicolumn{2}{|c|}{ 加熱温度 (JIS) } & 20 & - & - & 725 & - & - & 815 & - & - & 860 & - & - & 900 & - & - & 945 & - & - & 985 & - & - & 1030 & - & - \\
\hline
\end{tabular}




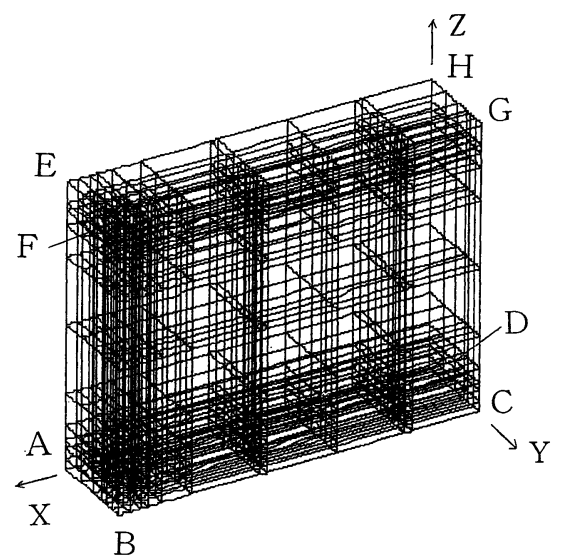

図-4 要素分割図

図-4 はモデルの要素分割であり，座標軸に平行な面 で分割し， 726 個の 6 面体，20 節点のアイソパラメト リック要素を設定した。節点総数は 3720 個である。

$\mathrm{ADHE}$ の面は $\mathrm{Y}$ 方向の変位が $0, \mathrm{CDHG}$ の面は $\mathrm{X}$ 方向の変位が $0, \mathrm{EFGH}$ の面は $\mathrm{Z}$ 方向の変位が 0 , 他は 節点力が 0 の境界条件を与えた。なおここで上部 RC スラブとの接合面は火災時も平面であると仮定し, EFGH 面に生じる鉛直変位を無視している。加熱途中 の損傷はなく形状は初期と同じと仮定して原点からの割 線によるヤング率を用いて，各経過時間での個別の計算 を行った。数值計算はプログラムが公開されているソフ ト16)を用いて行った。

(2) 接合面に生じる応力の計算結果

図-5 は, 加熱時間の経過に対して接合面に生じる応 力がどのように変化するかを, 梁側面の接合面上につい て示している。加熱開始後 20 分から 40 分の間に応力が 極大になるときがあり, その時刻は接合面の位置で多少 異なっている。加熱 20〜40 分後において応力が極大に なるのは, これ以後温度が上昇するにつれて線膨張量の
差の影響よりヤング率の低下による応力緩和の影響が大 きいからである。応力が最大であるのは, 垂直応力度 $\sigma_{y}$ とせん断応力度 $\tau_{y z}$ のいずれにおいても加熱後 20 分の ときであり, その位置は $\mathrm{Y}=110 \mathrm{~mm}, \mathrm{Z}=15 \mathrm{~mm}$ (GRC 打込み型枠の底板と側板の境目の位置の接合 面）である。

加熱 20 分のときの梁側面の接合面上の応力を図 -6 に, 梁底面の接合面上の応力を図一7に示す。面に垂直 な垂直応力度と面に平行なせん断応力度は, いずれも $\mathrm{GRC}$ 打込み型枠の底板と側板の境目 $(\mathrm{Y}=110 \mathrm{~mm}$, $\mathrm{Z}=15 \mathrm{~mm}$ ) に近いほど大きくなる傾向を示している。 その傾向から応力の分布が多少ずれる箇所があるが，そ れは主筋に近接した箇所（梁側面では $Z=50 \mathrm{~mm}$ と 350 $\mathrm{mm}$, 梁底面では $\mathrm{Y}=75 \mathrm{~mm})$ の付近である。図 -6 と 図一7 はあばら筋に近い位置 $(\mathrm{X}=100 \mathrm{~mm})$ とあばら筋 から離れた位置 $(X=200 \mathrm{~mm})$ について示しており, 両 者に多少の差が出るのはあばら筋の影響である。

図-8 は, 梁の長さ方向 (X 軸方向) での応力の分布

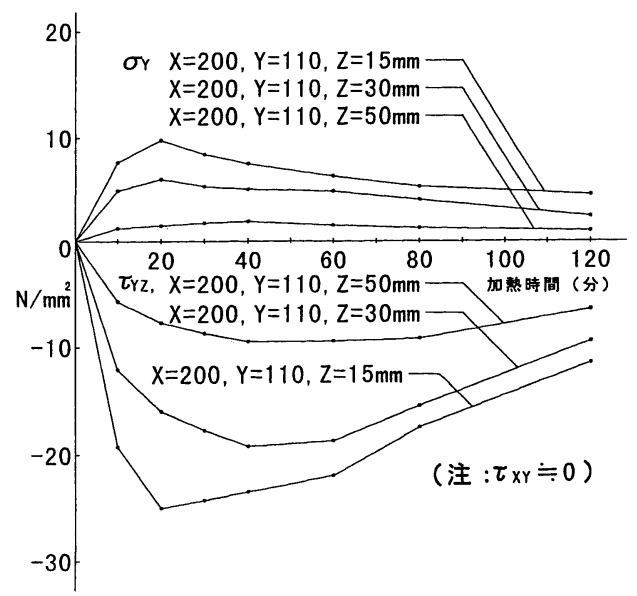

図 -5 梁側面の接合面上の応力

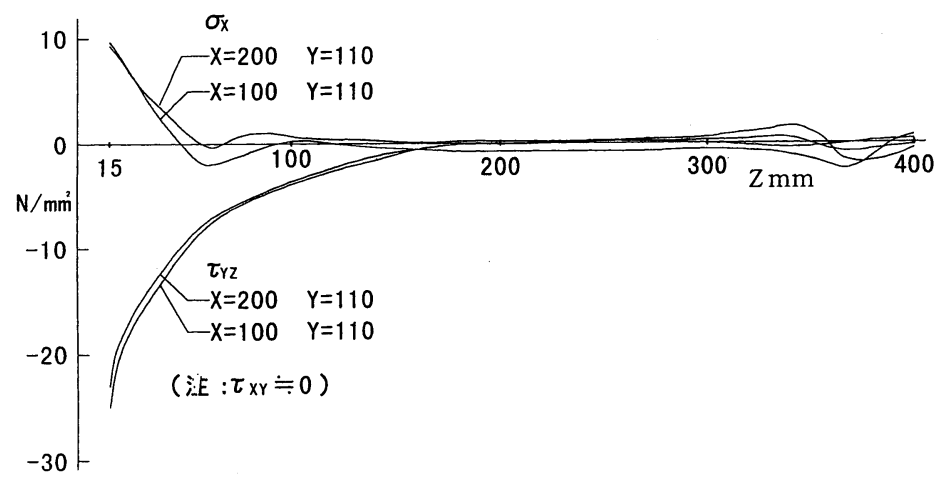

図 -6 梁側面の接合面上の応力

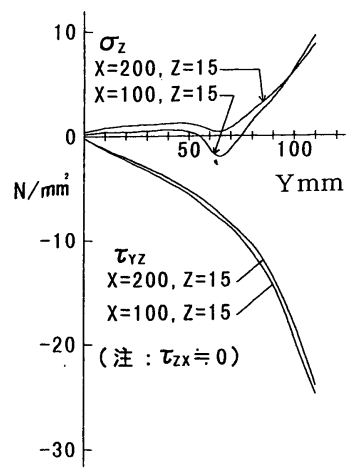

図 -7 梁底面の接合面上の応力 


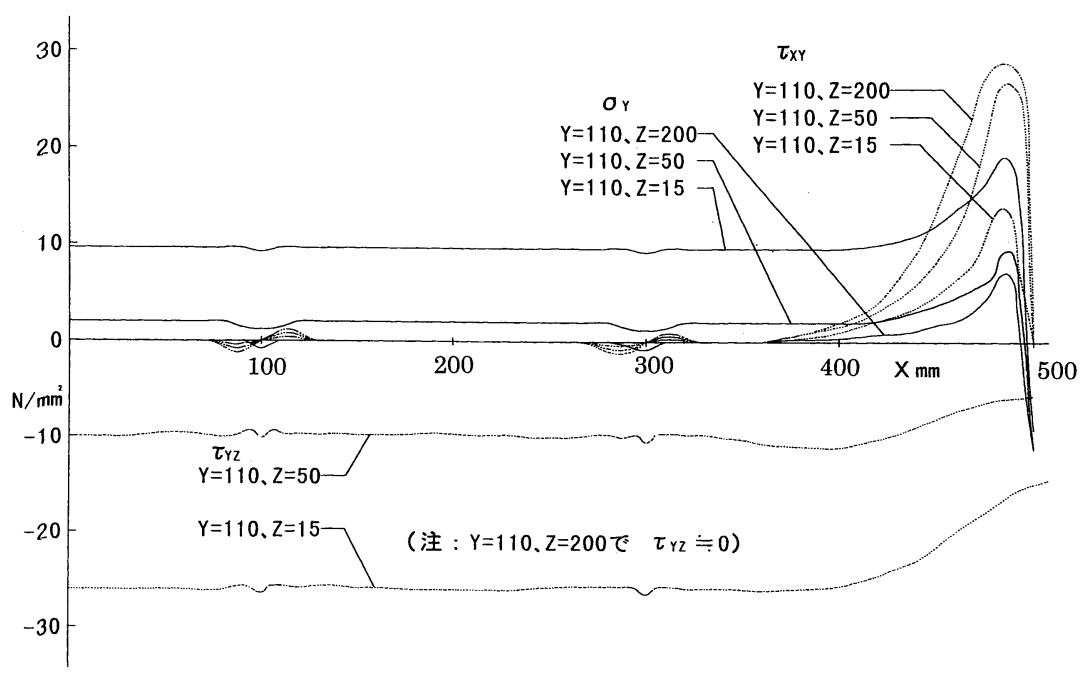

図-8＼cjkstart梁の長さ方向での応力分布

を示している。X が 0 300 mm の間において応力はほ ぼ一定の值である。 X=100 $\mathrm{mm}$ と $300 \mathrm{~mm}$ で少し変 動しているのは，この位置にあるあばら筋の影響であ る。X が $400 \mathrm{~mm}$ の所から応力の值が変化し, X が $500 \mathrm{~mm}$ すなわち, 梁小口（図-1 の ABFE の面）に 近づくほどその変化の割合が急激になり, 梁小口に近い 箇所で大きな応力が生じている。

(3) 接合面の応力に関する考察

図-8に示したように, 梁小口から離れた部分では, 接合面に生じる応力は, 梁の軸方向に変化が小さい。 $\mathrm{GRC}$ 打込み型枠を用いた $\mathrm{RC}$ 梁は，通常端部を柱また は大梁に接続され小口がないので，火災時の性質を検討 するには，小口に近い部分でなく小口から離れた部分が 対象になる。

小口から離れた部分では, 接合面上の最大の応力は, 加熱後 20 分のときに, GRC 打込み型枠の底板と側板の 境目の位置の接合面に生じ，接合面に垂直な引張応力度 は約 $9 \mathrm{~N} / \mathrm{mm}^{2}$, 接合面に平行なせん断応力度は約 25 $\mathrm{N} / \mathrm{mm}^{2}$ である。

梁小口から離れた部分において最初に損傷の起きる位 置は, 最大の応力が生じる $\mathrm{GRC}$ 打込み型枠の底板と側 板の境目近傍の接合面と考えられる。ただし，図一1に 示す耐火試験体の全体で見ると，梁小口の近くに大きな 応力が生じており, 耐火試験体の接合面の損傷は, 梁小 口の付近で最初に起きると考えられる。

なお解析モデルは要素ごとの温度の分布を一定として いるため, 本来連続した温度の分布を隣り合った要素の 境目で不連続として計算した。そのため, 接合面の応力 の計算結果は実際より大きくなるという誤差を含んでい る。また加熱過程で生じる局所的な損傷の影響は考慮し

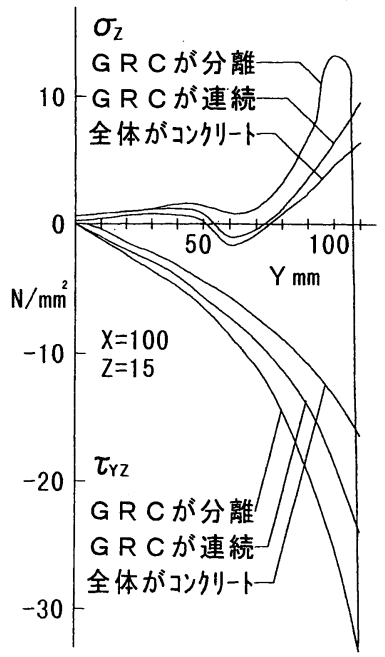

図-9 底面の接合面に生じる応力

ていない。

（4） GRC 打込み型枠の底板と側板の連続性につい $\tau$

GRC 打込み型枠の底板と側板を一体的に成形し両者 が連続した構成の場合と, 底板と側板を組み立てて両者 が分離した場合を比較した。図-2の $\mathrm{Z}=15 \mathrm{~mm}, \mathrm{Y}=$ 110 125 mm の位置の面上で， GRC 打込み型枠の底 板と側板に属する節点をそれぞれ別に設けて，この面で 底板と側板の間に応力が伝達しないモデルを作成した。 $\mathrm{GRC}$ 打込み型枠の底板とコンクリートとの接合面に生 じる応力の計算結果は図-9になる。

図-9のように, GRC 打込み型枠の底板と側板が分離 している場合は, 連続している場合に比べてコンクリー 
トと $\mathrm{GRC}$ 打込み型枠の接合面に生じる応力は大きく， また $\mathrm{Y}=110 \mathrm{~mm}$ すなわち底板と側板の境目で応力が搪 大しており特異性が表れている。このように接合された 箇所と接合されていない箇所の境目が特異点となり，脆 性的性質を持つ材料では不安定破壊の原因になって接合 面が急激に虽離することになる。したがって GRC 打込 み型枠の底板と側板が連続した構成にする方が, コンク リートとの接合面の剝離を抑えるのに有利であると考え られる。

なお図-9には, GRC 打込み型枠を用いずに全体がコ ンクリートの場合についての計算結果を示している。図 -9のように, GRC 打込み型枠を用いた場合は全体がコ ンクリートの RC 梁より接合面に生じる応力が大き い。

（5） GRC 打込み型枠とコンクリートの接合性能の 検討

GRC 打込み型枠とコンクリートの接合面は，引張強 度とせん断強度が大きいものほど，また強度に達した後 も完全に分離するのではなく投錨効果等により接続して いるものが望ましい。

円形凹みを付けた内面形状と亀甲金網を半分埋設した 内面形状の GRC 打込み型枠がコンクリートとの接合性 に優れており, $1 \mathrm{~N} / \mathrm{mm}^{2}$ 程度の引張強度と $4 \mathrm{~N} / \mathrm{mm}^{2}$ 程度の見掛けのせん断強度を有し, 強度に達してキレッ が生じた後も分離せずにある程度の応力を伝達できるこ とが報告されている1),17)。これらの内面形状の GRC 打込み型枠を用いた場合でも, 前述の接合面に生じる応 力の計算結果とその考察を検討すると, GRC 打込み型 枠の底板と側板の境目の近傍の接合面にキレツなどの損 傷が起きると考えなければならない。

なおこれらのキレツなどの損傷の影響は解析していな い。

\section{3. 耐火試験}

前述の検討結果から，円形凹みと金網埋設の内面形状 をもち底板と側板が連続した構成の GRC パネルを打込 み型枠に用いることが適当と考えられ，これらを用いて $\mathrm{RC}$ 梁の試験体を作成し，在来のコンクリートのみの $\mathrm{RC}$ 梁の試験体と共に耐火試験を行い耐火性能を調べ た。GRC 打込み型枠を用いた $R C$ 梁の常温における部 材構造試験で性能を確認しているので7),8)，ここでは 鉄筋の温度で判定する無載荷加熱による耐火試験を用い た。

\section{1 試験体作成方法}

\section{(1) GRC 打込み型枠}

GRC 打込み型枠は，表-2 に示す調合を用い，プレ ミックス成形法にて作成した。試験体の断面寸法は, 実
表-2 GRC の調合

\begin{tabular}{|c|c|}
\hline 使用 原 材 料 & 重 量 比 (\%) \\
\hline 普通ポルトランドセメント & 27.9 \\
\hline 砂 & 53.3 \\
\hline マイクロシリカ & 1.7 \\
\hline 水 & 1.3 \\
\hline 耐アルカリ硝子繊 維 & 3.1 \\
\hline 水 & 12.7 \\
\hline
\end{tabular}

際に耐火試験の行われる標準的な断面寸法である幅 250 $\mathrm{mm}$ 高さ $400 \mathrm{~mm}$ とし, 長さは大型試験炉の場合, $4000 \mathrm{~mm}$ の試験体を使うことが多いが，今回使用した 試験炉の大きさの関係から図-1に示したように 1000 $\mathrm{mm}$ とした。また, 端部小口を耐火被覆すると加熱面 積が減少し, 有利な条件となることから, 図-8 に示す 解析結果のように試験体小口の接合面に最も大きな応力 が発生し不利な条件となるものの, 試験体の両端小口面 の耐火被覆を行わず試験することとした。

1) 円形凹み $\mathrm{GRC}$ 打込み型枠

円形凹み GRC 打込み型枠は, 市販されているポリエ チレン気泡シートを GRC 成形用金型の内面に両面テー プで接着し，プレミックス GRCを打設した。硬化脱型 後 GRC 側に持ち込まれたシートを虽がし, GRC 内面 に, 直径 $10 \mathrm{~mm}$, 深さ $4 \mathrm{~mm}$, ピッチ $14 \mathrm{~mm}$ の円形凹 凸模様をつけた。図一10に円形凹み $\mathrm{GRC}$ 打込み型枠の 構造図を示す。

2) 金網埋設 GRC 打込み型枠

金網埋設 GRC 打込み型枠の作成は，底板と側板の部 分を蝶番でつないだ型を広げ, GRC を所定厚の半分ま で打設した後, 線径 $1.6 \mathrm{~mm}, 26 \times 38 \mathrm{~mm}$ の網目状亜 鉛引き亀甲金網を $30 \times 30 \mathrm{~mm}$ の角材を用いて $60 \mathrm{~mm}$ ピッチの凹凸状に型押ししたものを乗せ, 残りの GRC を打設した。GRCが半硬化状態の際に, 蝶番から折り 曲げ，底板と側板の GRC は連続した構成とした。な

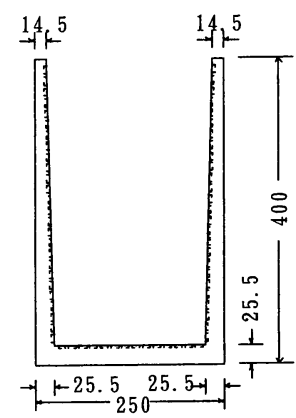

縦断面

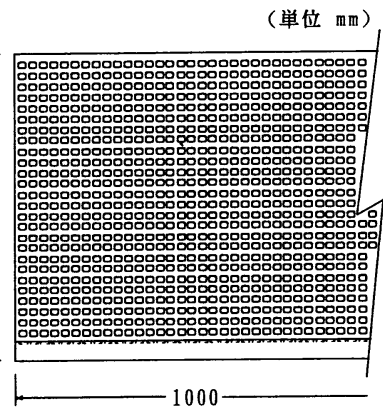

横断面
図-10 円形凹み $\mathrm{GRC}$ 打込み型枠構造図 


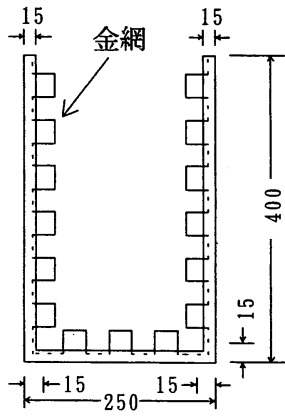

縦断面

図-11 金網埋設 GRC 打込み型枠構造図

お，コーナー部は空洞が生じないようにコテ仕上げを 行った。図一11に金網埋設 GRC 打込み型枠の構造図を 示す。

これらの GRC 打込み型枠は成形後, 一次養生として $60^{\circ} \mathrm{C}$ の蒸気養生を 6 時間行った後, 室内に 1 力月保管 する二次養生を行った。

(2) RC 梁試験体

$\mathrm{GRC}$ 打込み型枠は, コンクリート打設のときに型枠 のはらみなどの変形が起きないように仮説の支持台上に 設置した。その後, あらかじめ定められた位置に熱電対 がセットされた鉄筋を型枠内に配筋した。鉄筋は，主筋 がSD 295 D22 を, 試験体上下左右位置に計 4 本，あば ら筋が SD 295 D10を, $200 \mathrm{~mm}$ ピッチで長手方向に 4 本配筋した。配筋後, 表-3に示す調合および品質のコ ンクリートを打設した。なお，比較用として，GRC 打 込み型染を用いない在来 $\mathrm{RC}$ 梁を作成した。在来 $\mathrm{RC}$ 梁は合板型枠に配筋して表 -3 に示す調合のコンクリー トを打設し, 1 週間後に合板型枠を脱型した。

$\mathrm{GRC}$ 打込み型枠 $\mathrm{RC}$ 梁および在来 $\mathrm{RC}$ 梁は，コンク リートが硬化した後に，あらかじめ成形された中央部に 熱電対引き出し穴のあいた $600 \times 1900 \times 120 \mathrm{~mm}$ の床 スラブを想定した $\mathrm{RC}$ 板をその上部に取り付けた。こ の上部 $\mathrm{RC}$ スラブと $\mathrm{RC}$ 梁の固定方法は, $\mathrm{RC}$ 梁のコン クリート打設の前に, 両端のあばら筋近傍位置にあらか

\begin{tabular}{|c|c|c|c|c|c|}
\hline \multirow{5}{*}{ 調 合 } & \multicolumn{4}{|c|}{ 普通ポルトランドセメント } & \multirow{2}{*}{$\begin{array}{l}290 \mathrm{~kg} / \mathrm{m}^{3} \\
844 \mathrm{~kg} / \mathrm{m}^{3}\end{array}$} \\
\hline & 細 & & & 材 & \\
\hline & 粗 & & & 材 & $1018 \mathrm{~kg} / \mathrm{m}^{3}$ \\
\hline & 混 & & & 剂 & $3.07 \mathrm{~kg} / \mathrm{m}^{3}$ \\
\hline & 単 & 位 & 水 & 量 & $167 \mathrm{~kg} / \mathrm{m}^{3}$ \\
\hline \multirow{3}{*}{ 品 質 } & ス & ラ & ン & プ & $18.0 \mathrm{~cm}$ \\
\hline & 空 & & & 量 & $4.5 \%$ \\
\hline & 圧 & 縮 & 強 & 度 & $26.0 \mathrm{~N} / \mathrm{mm}^{2}$ \\
\hline
\end{tabular}

じめセットされた埋め込み金物に上部 $\mathrm{RC}$ スラブの座 堀り穴から長ボルトを通し固定した。この場合, 加熱さ れる梁部に対し上部 RC スラブは温度が低いことか ら, 試験体両端の固定部において拘束力が働き, 打込み 型枠は膨張し，その中央部においてコンクリートと豩離 しようとする力が働くと予想される。

$\mathrm{RC}$ 梁試験体は材齢 1 力月まで室内に静置した後, 含 水率測定用のダミ一試験体とともに強制乾燥を行い, 含 水率が建設省指定試験機関で耐火試験が行われる条 件 ${ }^{18)}$ である $5 \%$ 以下に下がったことを確認して耐火試 験を行った。

（3）試験体構造および測温位置

円形凹み $\mathrm{GRC}$ 打込み型枠 $\mathrm{RC}$ 梁, 金網埋設 $\mathrm{GRC}$ 打 込み型枠 $\mathrm{RC}$ 梁, 在来 $\mathrm{RC}$ 梁の構造および鉄筋の測温 位置を示す小口断面図をそれぞれ図-12，13，14に，ま た, 試験体の側面から見た共通断面図を図-15に示す。 ここで, 通常, 耐火試験において, 梁上部は上部 $\mathrm{RC}$ スラブからの冷却効果により温度上昇が低いことから,

$\mathrm{GRC}$ 打込み型枠 $\mathrm{RC}$ 梁では上部のかぶり厚さを 20 $\mathrm{mm}$ とした。なお，在来 $\mathrm{RC}$ 梁では，建築基準法で定 められているとおり一律 $30 \mathrm{~mm}$ とした。つまり, $\mathrm{GRC}$ 打込み型枠 $\mathrm{RC}$ はりのかぶり厚さは, 上部あばら 筋 $20 \mathrm{~mm}$, 上端主筋 $30 \mathrm{~mm}$ であるが在来 $\mathrm{RC}$ 梁のそ れらは，上部あばら筋 $30 \mathrm{~mm}$, 上端主筋で $40 \mathrm{~mm}$ で ある。下部あばら筋および下端主筋では, いずれの試験 体も前者が $30 \mathrm{~mm}$, 後者が $40 \mathrm{~mm}$ である。なおかぶ り厚さは鉄筋表面から試験体表面までの距離であり

（単位 $\mathrm{mm}$ )

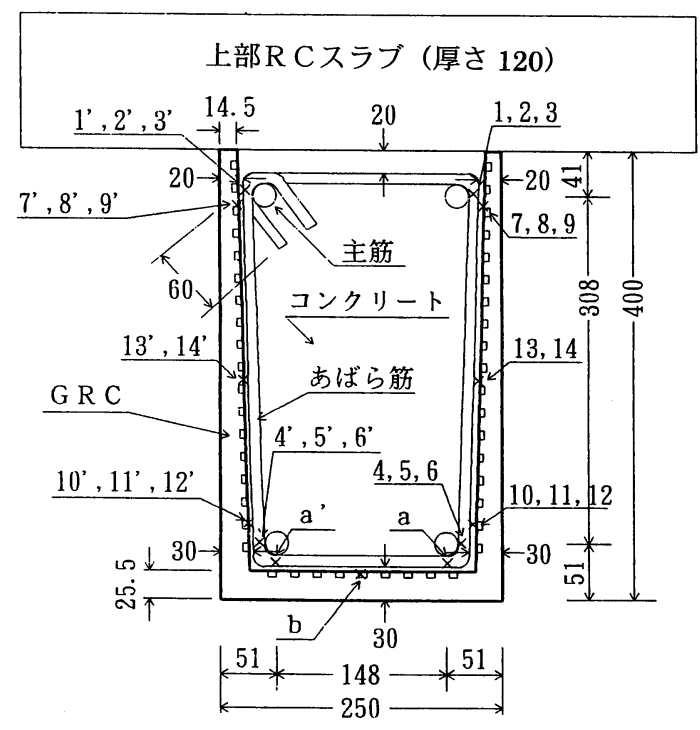

図-12 円形凹み $\mathrm{GRC}$ 打込み型枠 $\mathrm{RC}$ 梁 


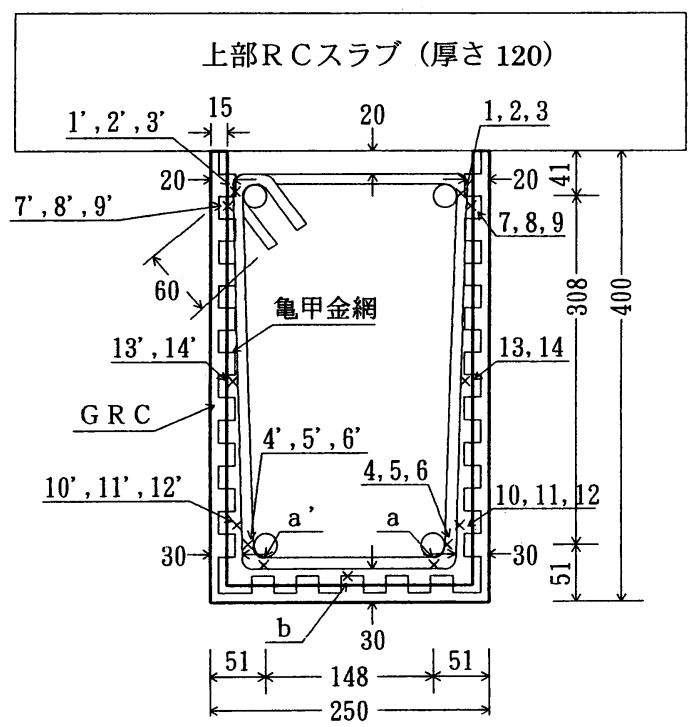

図-13 金網埋設 GRC 打込み型枠 $\mathrm{RC}$ 梁

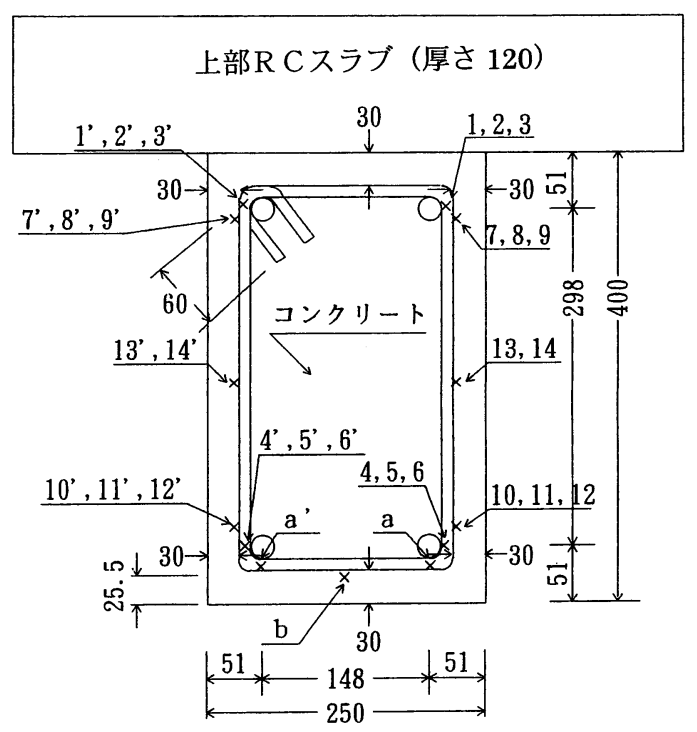

図-14 在来 $\mathrm{RC}$ 梁

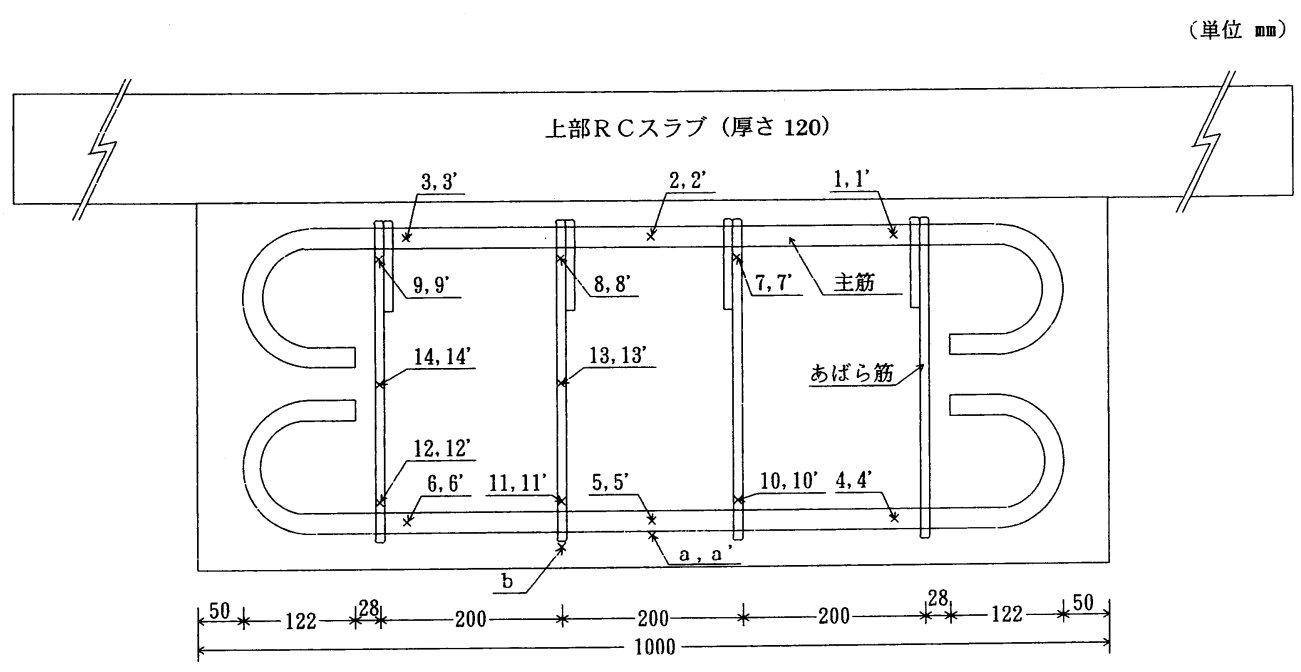

図一15 試験体共通横断面図

GRC 板の厚さを含んだ值である。測温位置について は，主筋，上部と中央部之下部のあばら筋および鉄筋温 度の最も上昇すると思われる位置に熱電対を取りつけ た。

図-12〜15において，1,2,3，1'，2'，3’ は上端主筋の 側面に取り付けられた熱電対位置を，また，4,5,6，4， 5’, 6’ は下端主筋の側面に取り付けられた熱電対位置を 示す。また, 7,8,9, 7'，8'，9’ は上部あばら筋側面位置 に, 10,11,12,10'，11'，12' は下部あばら筋側面位置 に，また，13,14，13'，14' は中央部あばら筋側面位置に
取り付けられた熱電対位置を示す。また, a, a' は下端 主筋下面位置に, b はあばら筋下面位置に取り付けられ た熱電対位置を示す。

\section{2 試験方法}

耐火試験は, JIS A 1304 建築構造物の耐火試験方法 の「はり」の 2 時間耐火試験方法に準拠して行った。実 際に使用した試験炕は, 図-16に示す形状のもので, 下 方と左右側面からプロパンガスバーナにて試験体を標準 加熱曲線に沿って 2 時間加熱し，加熱中および加熱後の 鉄笳の温度を測定した。炉内には, 試験体の左右各 3 力 


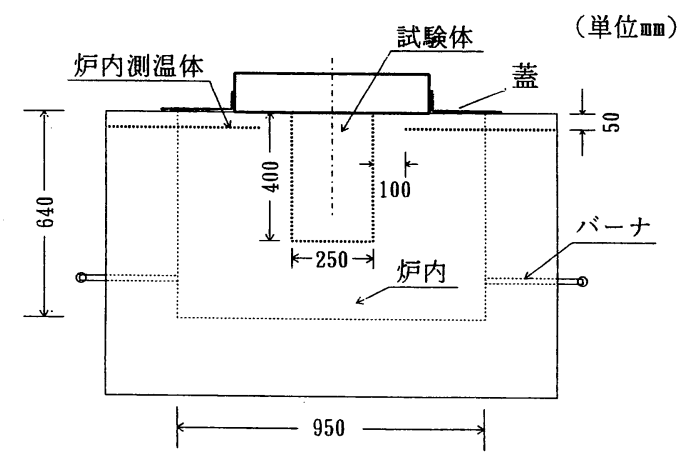

正面図

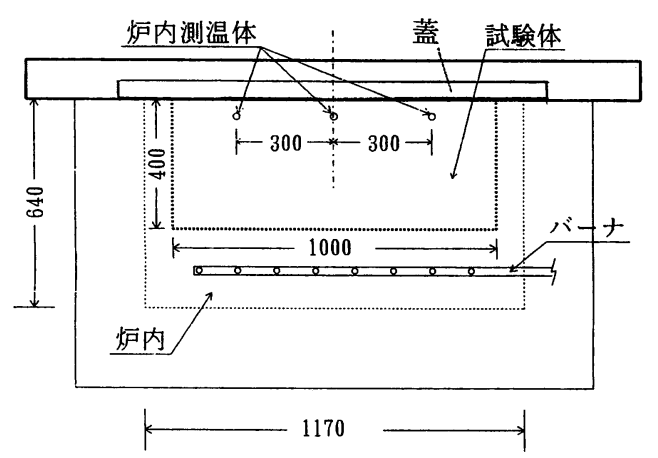

側面図

図-16 耐火試験状況

表-4 GRC 打込み型枠 $\mathrm{RC}$ 梁および在来 $\mathrm{RC}$ 梁の 2 時間耐火試験での各部の測温結果

\begin{tabular}{|c|c|c|c|c|c|c|c|c|c|}
\hline \multirow[b]{2}{*}{ 加熱経過 } & \multirow{3}{*}{$\begin{array}{ll}\text { 試 } & \text { 験 } \\
\text { 体 } \\
\text { 種 } & \text { 類 }\end{array}$} & \multicolumn{8}{|c|}{ 温 度 $\left({ }^{\circ} \mathrm{C}\right.$ ) (平均值) } \\
\hline & & 上端主筋側面 & 下端主筋側面 & 上部あばら筋 & 下部あばら筋 & 中部あばら筋 & 下端主筋下部 & あばら筋下部 & 炉内温度 \\
\hline & & $1,2,3,1^{\prime}, 2^{\prime}, 3^{\prime}$ & $4,5,6,4^{\prime}, 5^{\prime}, 6^{\prime}$ & $7,8,9,7^{\prime}, 8^{\prime}, 9^{\prime}$ & $\begin{array}{l}10,11,12,10^{\prime} \\
11^{\prime}, 12^{\prime}\end{array}$ & $13,14,13^{\prime}, 14^{\prime}$ & $\mathrm{a}, \mathrm{a}^{\prime}$ & b & $41 \sim 46$ \\
\hline \multirow{3}{*}{0 分 } & 円形凹み & 14.4 & 14.3 & 14.3 & 14.2 & 14.6 & 14.5 & 19.7 & 24.0 \\
\hline & 金網埋設 & 5.8 & 6.1 & 5.3 & 6.8 & 6.0 & 8.1 & 7.0 & 47.5 \\
\hline & 在来 $\mathrm{RC}$ & 24.6 & 24.4 & 24.5 & 24.1 & 24.4 & 24.1 & 24.4 & 94.4 \\
\hline \multirow{3}{*}{30 分 } & 円形凹み & 92.5 & 110.2 & 146.5 & 118.8 & 117.1 & 115.9 & - & 893.5 \\
\hline & 金網埋設 & 97.3 & 127.4 & 132.2 & 161.1 & 147.4 & 124.4 & 178.6 & 864.0 \\
\hline & 在来 $\mathrm{RC}$ & 104.8 & 127.5 & 155.6 & 198.0 & 191.4 & 162.5 & 117.1 & 859.4 \\
\hline \multirow{3}{*}{60 分 } & 円形凹み & 165.1 & 270.2 & 263.6 & 296.1 & 255.2 & 266.2 & - & 937.4 \\
\hline & 金網埋設 & 146.6 & 331.8 & 250.7 & 369.5 & 310.5 & 329.1 & 387.0 & 945.5 \\
\hline & 在来 $\mathrm{RC}$ & 179.2 & 305.2 & 273.3 & 384.1 & 342.6 & 349.8 & 283.0 & 936.4 \\
\hline \multirow{3}{*}{90 分 } & 円形凹み & 230.2 & 412.9 & 344.8 & 432.9 & 359.4 & 409.0 & - & 984.8 \\
\hline & 金網埋設 & 216.1 & 484.4 & 336.0 & 508.1 & 425.2 & 482.6 & 527.7 & 986.5 \\
\hline & 在来 $\mathrm{RC}$ & 249.9 & 444.9 & 357.3 & 508.2 & 440.6 & 484.0 & 424.1 & 999.1 \\
\hline \multirow{3}{*}{120 分 } & 円形凹み & 283.7 & 523.7 & 405.5 & 536.1 & 444.0 & 520.1 & - & 1007.1 \\
\hline & 金網埋設 & 278.0 & 595.0 & 402.6 & 610.7 & 507.7 & 592.9 & 630.3 & 1011.2 \\
\hline & 在来 $\mathrm{RC}$ & 307.7 & 545.1 & 422.9 & 596.1 & 514.8 & 579.0 & 526.6 & 1034.6 \\
\hline \multirow{3}{*}{ 最 大 } & 円形凹み & 294.0 (130 分) & 558.9 (137 分) & 409.6 (123 分) & 555.2 (130 分) & 456.2 (127 分) & 556.8 (138 分) & - & 1007.1 (120 分) \\
\hline & 金網埋設 & 295.1 (136 分) & 623.1 (133 分) & 410.1 (126 分) & 626.2 (128 分) & 517.6 (126 分) & 621.1 (134 分) & 641.5 (126 分) & $1011.2(120$ 分 $)$ \\
\hline & 在来 $\mathrm{RC}$ & 324.9 (136 分) & 575.6 (137 分) & 431.5 (126 分) & 607.2 (127 分) & 523.1 (126 分) & 590.1 (136 分) & 560.5 (138 分) & 1034.6 (120 分) \\
\hline \multirow{3}{*}{150 分 } & 円形凹み & 275.0 & 545.1 & 324.5 & 514.7 & 393.6 & 544.4 & - & 320.6 \\
\hline & 金網埋設 & 287.2 & 594.7 & 352.8 & 569.4 & 452.7 & 594.5 & 569.0 & 352.1 \\
\hline & 在来 $\mathrm{RC}$ & 315.9 & 560.6 & 372.1 & 545.2 & 451.0 & 557.3 & 550.9 & 302.9 \\
\hline \multirow{3}{*}{180 分 } & 円形凹み & 230.5 & 463.5 & 247.7 & 422.1 & 310.1 & 464.0 & - & 62.9 \\
\hline & 金網埋設 & 253.7 & 496.2 & 280.3 & 462.5 & 361.3 & 498.0 & 475.0 & 90.4 \\
\hline & 在来 $\mathrm{RC}$ & 279.6 & 482.7 & 307.7 & 452.6 & 373.0 & 471.4 & 481.8 & 203.2 \\
\hline
\end{tabular}

所, 直径 $1 \mathrm{~mm}$ の $\mathrm{CA}$ 熱電対を試験体側面から $3 \mathrm{~cm}$ 離した位置に置き, 加熱中の炉内温度誤差が加熱 1 時間 までは土 $10 \%$ 以内， 2 時間までは $\pm 7.5 \%$ 以内になるよ うに制御した。加熱が終了し, 鉄筋の温度が降下したこ とを確認してから試験体を炉から取り出し, 接合面の状 況について調べるなど外観の目視検査を行った。

\section{3 試験結果}

\section{(1) 鉄筋の測温結果}

鉄筋温度の測定結果を表 4 に示す。 GRC とコンク リートの分離により, 鉄筋の温度が急激に上昇するよう な現象は観察されなかった。試験体の種類, および測温 場所により異なるが，おおむね加熱開始から 125～140 


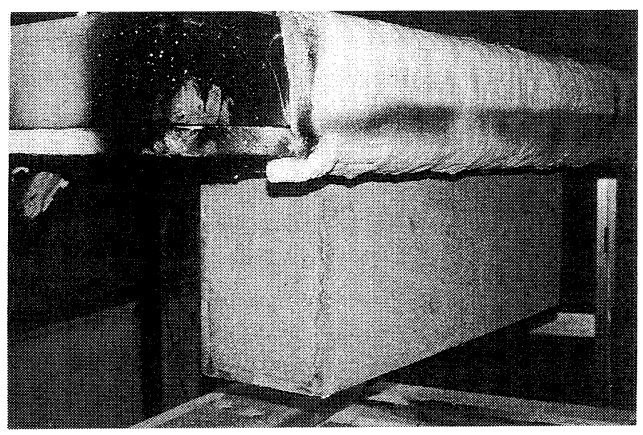

写真-1 円形凹み GRC 打込み型枠 RC 梁加熱試験後の外観

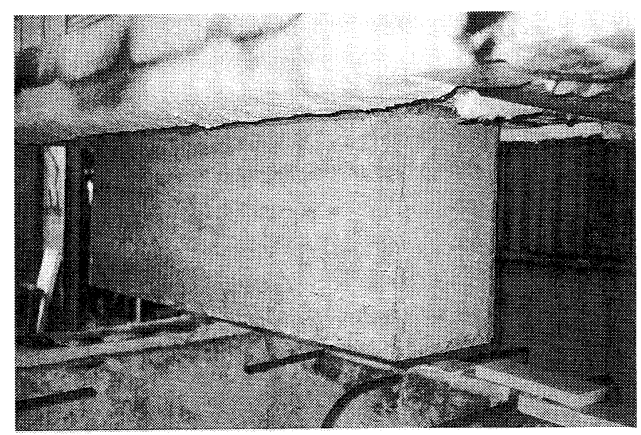

写真-2 金網埋設 $\mathrm{GRC}$ 打込み型枠 $\mathrm{RC}$ 梁加熱試験後の外観

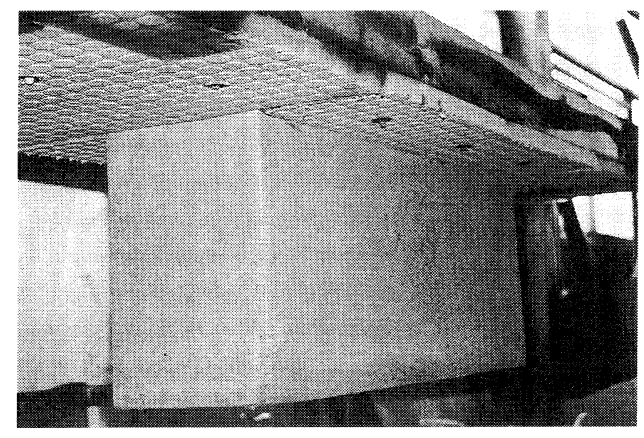

写真 -3 在来 $\mathrm{RC}$ 梁加熱試験後の外観

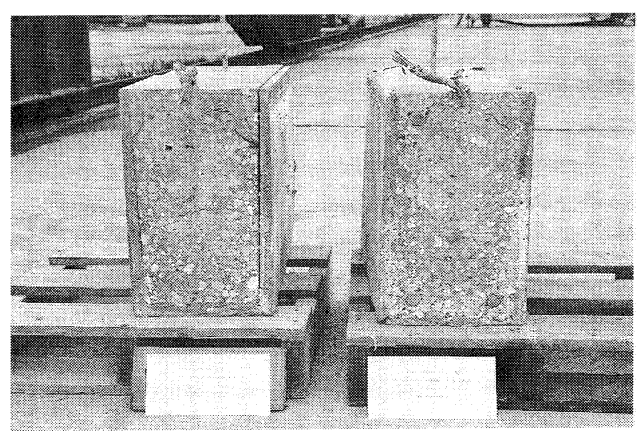

写真-4 加熱試験後の試験体切断断面。向かって左側が, 円 形凹み $\mathrm{GRC}$ 打込み型枠 RC 梁。右側が金網埋設 GRC 打込み型枠 RC 梁
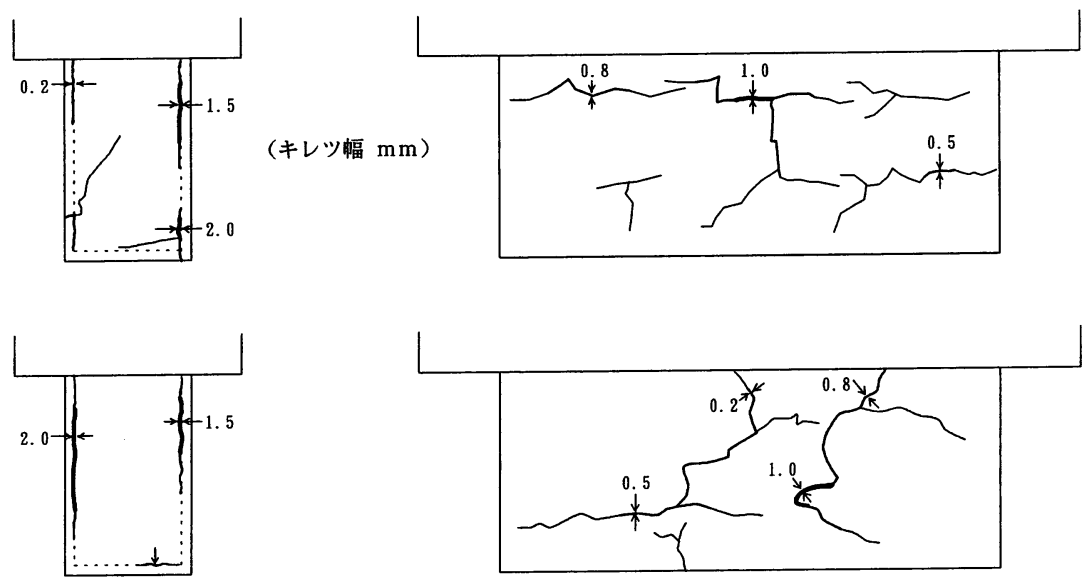

図-17 円形凹み GRC 打込み型枠 RC 梁加熱試験後のキレッ発生状況

分（加熱終了後 5〜20 分）で温度の最大值を示した。

（2）加熱後の試験体の外観検査結果

加熱終了後の外観を写真 -1 ～ ツ発生状況を図-17〜19に示す。キレツ幅については, 比較的大きくかつ目視で計測が可能な $0.2 \mathrm{~mm}$ 以上の 幅について図中に表記した。なお建築物の診断で，鉄筋
が錆びる恐れがあるかないかの判断の指標にキレツの幅 $0.2 \mathrm{~mm}$ 以上が用いられており，これも参考にした。 $0.2 \mathrm{~mm}$ 以下のキレツについては寸法の測定は行わずス ケッチにとどめた。GRC 打込み型枠 $\mathrm{RC}$ 梁については 加熱試験終了後の試験体について, それぞれ中央部から 切断し, 切断面を写真撮影した。その結果を写真 -4 に 

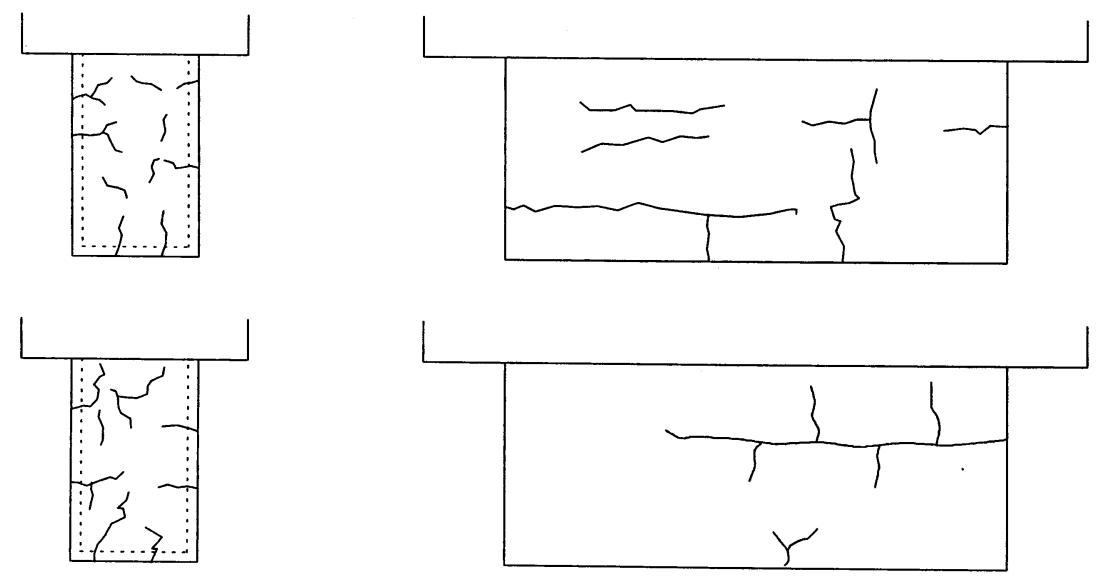

図-18 金網埋設 GRC 打込み型枠 $\mathrm{RC}$ 梁加熱試験後のキレッ発生状況
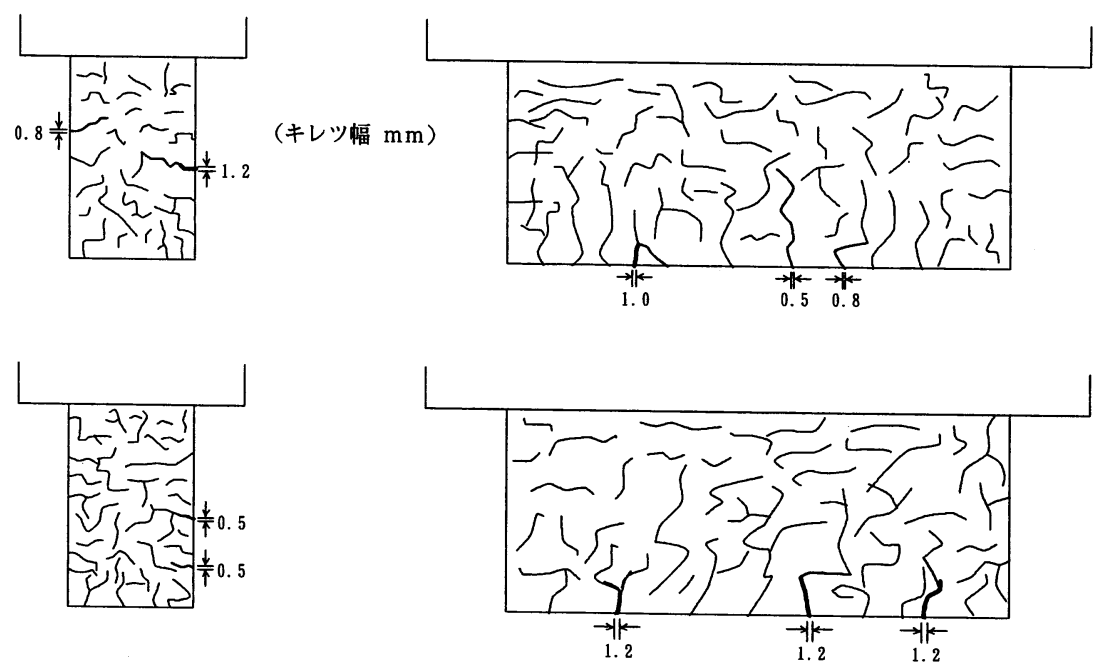

図-19 在来 RC 梁加熱試験後のキレッ発生状況

示す。写真 -4 から, 円形凹み $\mathrm{GRC}$ 打込み型枠 $\mathrm{RC}$ 梁 は接合面に若干の䟝離が見られるものの，金網埋設 $\mathrm{GRC}$ 打込み型枠 $\mathrm{RC}$ 梁は良好な状態を保っていた。な お，在来 $\mathrm{RC}$ 梁については，加熱終了後ハンドリング 過程中のコンクリート部の強度低下に起因するくずれが 激しく, 上記に示す切断は行えなかった。

\section{4. 考察}

表-4 の結果をもとに, 同じかぶり厚さにおける鉄筋 の温度をグラフにすると図-20２3に示すようになる。 図-20 が他のグラフに比べ, 全体的に温度が低い理由 は，上部 RC スラブが上方から加熱を受けないため, そこからの冷却効果が原因と考えられる。上に取り付け られた上部 RC スラブとその下の RC 梁の断面積比率 は約 $7: 10$ であり, 上部 $\mathrm{RC}$ スラブが及ぼす冷却効果
は大きい。また，図 -20 において，在来 $\mathrm{RC}$ 梁の測温 結果が, GRC 打込み型枠のそれらの值に比へてて高い値 を示した理由は，前者の鉄筋位置が後者に比べて上部 $\mathrm{RC}$ スラブより $10 \mathrm{~mm}$ 大きく下がっていて, 上部 $\mathrm{RC}$ スラブからの冷却効果を受けにくいためと考えられる。

図-21〜23 において，かぶり厚さの違いによる鉄筋の 昇温の違いがあまり見られなかった理由として, 鉄筋の 熱伝導率の影響が考えられる。つまり，鉄の熱伝導率が $55 \mathrm{~W} \cdot \mathrm{m}^{-1} \mathrm{~K}^{-1}$ であるのに対し ${ }^{19)}$, GRC 打込み型枠 もしくはコンクリートのそれは $1 \mathrm{~W} \cdot \mathrm{m}^{-1} \mathrm{~K}^{-1}$ であ る19),20)。したがって，鉄笳は，コンクリートの温度よ り接している鉄筋温度の影響をより大きく受ける。図 -21 のかぶり厚さ $30 \mathrm{~mm}$ はあばら筋の位置であり, 図 -22, 23 のかぶり厚さ $40 \mathrm{~mm}$ は主筋の位置である。 ばら筋の断面積に比べ，主筋のそれは 4.8 倍であること 


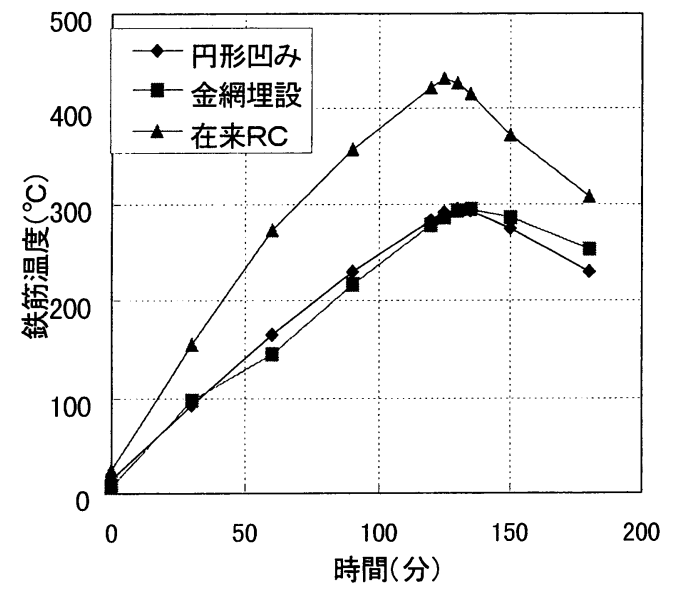

図-20 鉄筋温度の経時変化 (梁上・側面かぶり厚さ $30 \mathrm{~mm}$ )

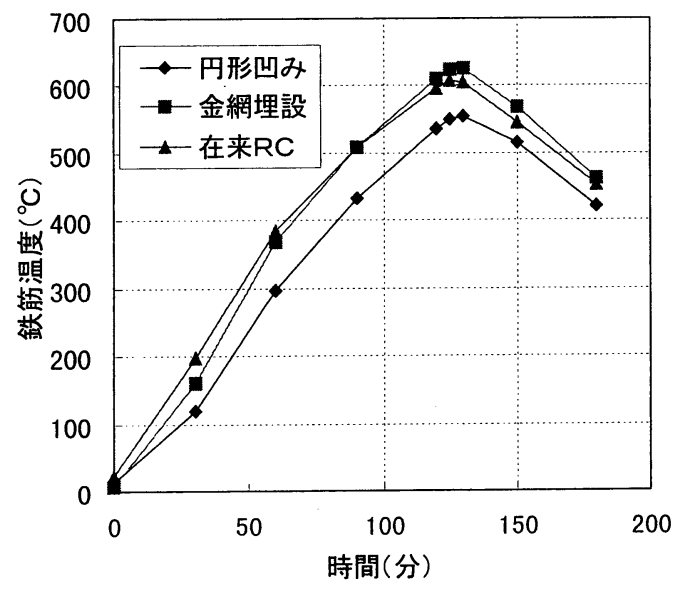

図-21 鉄筋温度の経時変化 (梁下・側面かぶり厚さ $30 \mathrm{~mm}$ )

\section{表 -5 耐火構造はりの 2 時間耐火試験判定結果}

\begin{tabular}{|c|c|c|c|}
\hline 判定条件 & $\begin{array}{l}\text { 円形凹 み } \\
\text { GRC 打込 } \\
\text { み型枠 RC } \\
\text { 梁試験体 }\end{array}$ & $\begin{array}{l}\text { 金 網 埋 設 } \\
\text { GRC 打込 } \\
\text { み型枠 RC } \\
\text { 梁試験体 }\end{array}$ & $\begin{array}{l}\text { 在 来 RC } \\
\text { 梁試験体 }\end{array}$ \\
\hline $\begin{array}{l}\text { 加熱中, 耐火上お } \\
\text { よび構造耐力上有 } \\
\text { 害な変形, 破壊, } \\
\text { 脱落の変化を生じ } \\
\text { ないこと }\end{array}$ & $\begin{array}{l}\text { GRC 打込 } \\
\text { み型枠の若 } \\
\text { 干の剝離あ } \\
\text { るも脱落に } \\
\text { は至らず }\end{array}$ & 問題なし & 問題なし \\
\hline $\begin{array}{l}\text { 加熱中鋼材の最高 } \\
\text { 温度が } 500^{\circ} \mathrm{C} \text { 以下 } \\
\text { であること }\end{array}$ & $\begin{array}{l}\text { 最高温度 } \\
536.19^{\circ} \mathrm{C} \\
※ 1)\end{array}$ & $\begin{array}{l}\text { 最高温度 } \\
630.3^{\circ} \mathrm{C} \\
※ 2)\end{array}$ & $\begin{array}{l}\text { 最高温度 } \\
596.1^{\circ} \mathrm{C} \\
※ 3)\end{array}$ \\
\hline $\begin{array}{l}\text { 構成材料の一部が } \\
\text { 不燃材料でないも } \\
\text { のにあっては; 加 } \\
\text { 熱終了後 } 10 \text { 分間 } \\
\text { 火気が残存しない } \\
\text { こと }\end{array}$ & $\begin{array}{l}\text { 火気の残存 } \\
\text { 見られず。 }\end{array}$ & $\begin{array}{l}\text { 火気の残存 } \\
\text { 見られず。 }\end{array}$ & $\begin{array}{l}\text { 火気の残存 } \\
\text { 見られず。 }\end{array}$ \\
\hline
\end{tabular}

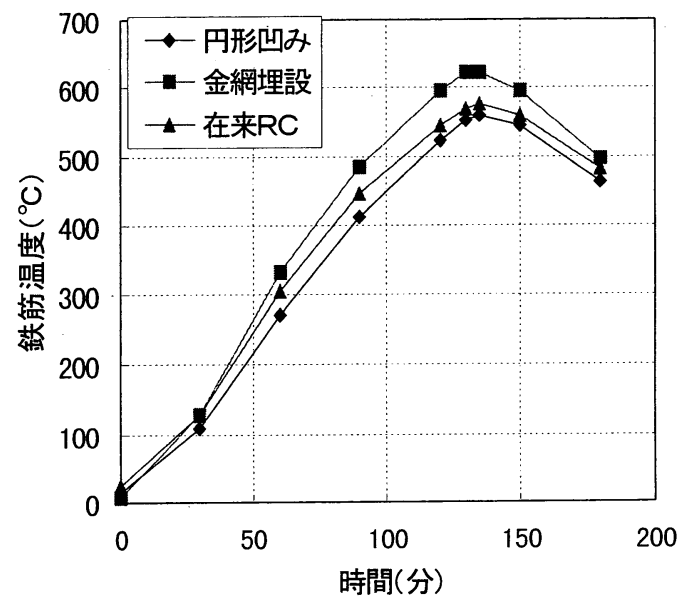

図一22 鉄筋温度の経時変化 (梁下・側面かぶり厚さ $40 \mathrm{~mm}$ )

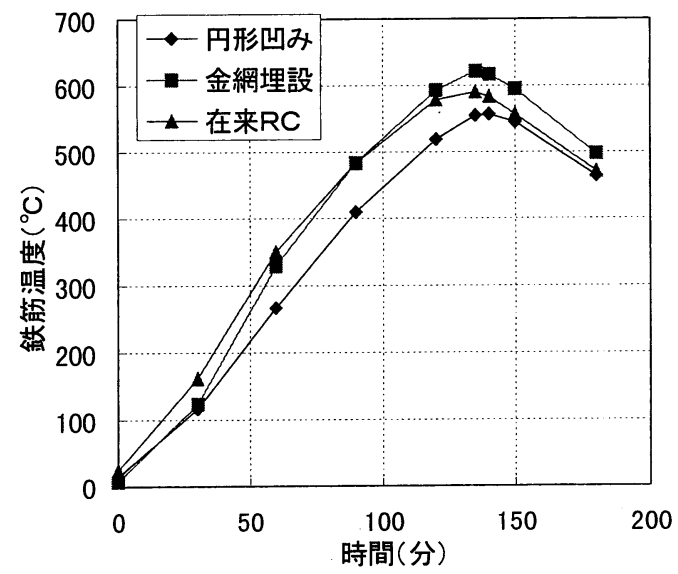

図-23 鉄筋温度の経時変化 (梁下・底面かぶり厚さ $40 \mathrm{~mm}$ )

から，熱容量的にも主筋温度に支配される。

図-21 23において，円形凹 $\mathrm{GRC}$ 打込み型枠 $\mathrm{RC}$ 梁が他のものに比べて鉄筋の昇温が若干低い理由とし て, 加熱中に, 図-17 および写真 -4 に示すように接合 面に部分的な豩離が生じ, 空気による断熱層が形成され たからと考えられる。ただし，この咏離も大きくなる と, 鉄筋温度の急激な上昇, さらには GRC 打込み型枠 の㓥落等の問題が生じるが, 今回, そのような問題は発 生しておらず, 耐火上有害な変形, 脱落は生じていな い。

一方，金網埋設 $\mathrm{GRC}$ 打込み型枠 $\mathrm{RC}$ 梁は，図 -18 お よび写真 -4 に示すように, 加熱後の䟝離は見られな かった。図 $-21 \sim 23$ の鉄筋温度も, 在来 $\mathrm{RC}$ 梁の鉄筋 温度の上昇と似た様相を呈している。金網埋設 GRC 打 込み型枠 $\mathrm{RC}$ 梁試験体の場合, GRC 打込み型枠に埋設 された金網の GRC 表層部からの距離が浅いので，その 
部分の発錆の恐れが考えられるが, GRC 打込み型枠 は, 組織が緻密であり中性化の進行は極めて遅いことが 確認されている ${ }^{9), 21) 。 ~}$

今回の耐火試験結果を, 建設省告示第 2999 号に規定 する「耐火構造のはりの 2 時間耐火試験」の判定基準に 照らし合わせると表-5に示すとおりとなる。

表 -5 から, 今回の試験体はいずれも鋼材温度が $500^{\circ} \mathrm{C}$ 以下の基準を超えた。基準の $500^{\circ} \mathrm{C}$ 以下になるべき在来 $\mathrm{RC}$ 梁の場合も超えており, 今回の試験体が小口耐火被 覆を施していないため, 加熱面積が大きくなり, 全体に 試験体の温度が上昇したためと考えられる。建築基準法 により在来 RC 梁は, 2 時間の耐火性能を有することが 認められており, 耐火性能判定に合格するには小口部分 を耐火被覆した大型はり試験体で確認する必要がある。

\section{5.まとめ}

$\mathrm{GRC}$ 打込み型枠を使用した $\mathrm{RC}$ 梁の耐火性能につい て, GRC 打込み型枠をかぶり厚さに含めるという前提 で検討し，以下のような知見が得られた。

（1） GRC 打込み型枠とコンクリートの接合面に生 じる応力を, 耐火試験の加熱開始から加熱 120 分までの 間について 3 次元有限要素法で計算した結果, GRC 打 込み型枠の底板と側板の境目近傍に最大の引張応力とせ ん断応力の発生が見られた。またこれらの最大の応力の 発生は, 加熱後 20 分程度経過した時であった。加熱時 にGRC 打込み型枠とコンクリートが分離するのを防ぐ には，コンクリートとの接合性能が高く，底板と側板が 連続した構成の GRC 打込み型枠を用いることが必要と 考えられた。

（2）コンクリートとの接合性能の高い円形凹み内面 形状または金網埋設内面形状で, 底板と側板が一体化す るように成形した GRC 打込み型枠を用いた $\mathrm{RC}$ 梁の 試験体を作成して耐火試験を行い，以下の結果を得た。

1）金網埋設 GRC 打込み型枠を使用した $\mathrm{RC}$ 梁 は, GRC とコンクリートとの付着性が優れ, 加熱後の 剝離も見られなかった。鉄筋の昇温も在来 $\mathrm{RC}$ 梁試験 体と同様な傾向を示した。

2) 円形凹み $\mathrm{GRC}$ 打込み型枠を使用した $\mathrm{RC}$ 梁 は, GRC 打込み型枠とコンクリートの接合面に部分的 な剝離が生じたが, 剥落には至らなかった。また, 單離 に伴う断熱層の形成により, 鉄筋の昇温傾向は他のもの に比べ低い傾向が見られた。

3）数值計算の結果では, GRC 打込み型枠とコンク リートの接合面の一部の箇所に強度より大きい応力が生 じたが，それらの箇所では耐火試験において部分的な接 合面の䟝離が見られただけで, 䟝落などは起きなかっ た。これは, GRC 打込み型枠の底板と側板を接続した
構成にしたこと、コンクリートとの接合性に優れた GRC 打込み型枠を用いたためと考えられ, GRC 打込 み型枠の適用においては底板と側板の連続性とコンク リートとの接合性が重要である。

（3）底板と側板が連続しかつコンクリートとの接合 性に優れた GRC 打込み型枠を使用した RC 梁は, 同 じ断面の在来 RC 梁と同程度の耐火性能を有し, GRC 打込み型枠をかぶり厚さに含めることが可能であると考 えられる。

（4）なお建築基準法が改定され，また耐火試験方法 が近く見直しになるので，これに対応して GRC 打込み 型枠を用いた $\mathrm{RC}$ 梁が構造部材としての耐火性能を有 することは載荷加熱試験により確認すべきである。また 数值解析で耐火性能を評価するには, 部材内の温度を連 続した分布として計算する必要がある。

[謝 辞] 本研究に協力いただいた日本 GRC 工業会 技術部会に感謝の意を表す。

\section{参 考 文 献}

1) 平居孝之ほか：GRC 打込み型枠とコンクリートの接合 面における応力伝達に関する基礎的考察, 日本建築学会 構造系論文集, 第 485 号, pp. 17 24, July 1996

2) 何 仕栄・平居孝之・村上 聖・福田亮治 : 接合面に凹 凸を付けたコンクリートのせん断応力伝達性能に関する 研究, コンクリート工学論文集, Vol. 18, No. 2, pp. 11〜 18, 1997

3）何 仕栄・平居孝之：表面にシャーキを付けたガラス緎 維補強セメントパネルとコンクリートの接合性状に関す る研究, 日本建築学会構造系論文集, No. 497, pp. 9〜 15, 1997

4) A.J. Majumdar and J.F. Ryder : Glass Fibre Reinforcement of Cement Products, Journal of Glass Technology, Vol. 9, No. 3, pp. 78-84, June 1968

5）鈴木由郎：耐アルカリ性ガラス, セラミックス, Vol. 1, 11, No. 7, pp. 54〜61, 1976

6) 岸谷孝一 : ガラス織維強化セメント/GRC, セメントコ ンクリート, No. 377, pp. 2〜4, July 1978

7）村上 聖ほか：GRC 打込み型枠による鉄筋コンクリー トはりの構造特性に関する実験的研究その 1 変形および 耐荷性状, 日本建築学会構造系論文集, 第 487 号, pp. $21 \sim 28,1996$

8）村上 聖ほか：GRC 打込み型枠による鉄筋コンクリー トはりの構造特性に関する実験的研究その 2 負荷の下で の GRC 打込み型枠の付着剝離性状, 日本建築学会構造 系論文集, 第 494 号, pp. 29 36, 1997

9）依田彰彦・横室 隆・平居孝之・藤田直明：GRC 打込 み型枠を使用した RC の中性化試験（III）, 第 11 回 GRC シンポジウム講演要旨集, pp. 1〜 4, 1999

10）竹内好雄・藤田直明・平居孝之：GRC 打込み型枠を使 用した梁の施工に関する考察, コンクリート工学年次論 文報告集, Vol. 20, No. 2, pp. 1219 1224, 1998

11）浜田 稔ほか: 建築学大系 21 建築防火論, 彰国社, pp. 202 230, 1970 
12) 原田 有: 建築耐火構法, 工業調查会, pp. 23 29, pp. 64 66, 1973

13）日本建築学会: 構造用教材, 日本建築学会, p 39, 1995

14）岸谷孝一ほか：GRC の物性之試験方法, 日本 GRC 工 業会, pp. 70 73, pp. 109 112, 1988

15） U. Schneider・森永 繁監訳 : コンクリートの熱的性 質, 技報堂出版, 1983

16) 平居孝之ほか：WINDOWS 95 対応パソコン 3 次元有 限要素法, 共立出版, 1997

17）前田孝一ほか：GRC 打込み型枠に関する研究 (1) 接着 試験と曲げ試験, 日本建築学会学術講演梗概集, pp. 529 530, 1996
18）建設省建築研究所：耐火構造等試験運用指針 - 防火材料 試験運用指針, p 1-4)-1, Mar. 1995

19）国立天文台編：理化年表，物 54-55, 1998

20）岸谷孝一ほか：GRC の物性と試験方法, 日本 GRC 工 業会, p 107, 1988

21）星野富夫・魚本健人 - 小林一輔：海洋環境下に長期間暴 露した各種被覆材料を施した鉄筋コンクリート梁の耐久 性之防食効果, コンクリート工学年次論文集, Vol. 18, No. 1, pp. 759 764, 1996

（原稿受理年月日 : 1999 年 1 月 10 日）

\title{
Fundamental Study on Fire Resistance Properties of Reinforced Concrete Beams Using GRC Casting Formworks
}

\author{
By Naoaki Fujita, Takayuki Hirai, Kiyoshi Murakami and Yoshiaki Sato
}

Concrete Research and Technology, Vol. 10, No. 3, Sept. 1999

Synopsis The tensile stress and shearing stress on the interface between the GRC casting forms and the concrete of the reinforced beam during fires were calculated by finite element method. Two types of GRC casting formworks were selected to improve joining performance between GRC and concrete. One was putting embossment and the other was burying wire net on the inside surface of GRC casting formworks. Fire resistance test was carried out on reinforced concrete beams covered with these GRC casting formworks and also to the reinforced concrete beam without GRC formwork. From these tests it was recognized that GRC formwork in which wire net was buried showed good joining performance between GRC and concrete. GRC formwork which has embossment on inside surface showed a little separation because the ascent of the temperature of the steel showed lower than in the other specimens and this fact was confirmed by the inspection of the specimen after the heating test but it was not so serious. It can be considered that RC beams using GRC permanent formworks have the similar degree of fire resistance properties with the conventional $\mathrm{RC}$ beam without formworks.

Keywords : glass fibre reinforced cement, casting formworks, reinforced concrete beam, fire resistance, bonding property 